\title{
Strategi Motivasi Green's, Gaya Baru Pembelajaran Matematika pada Siswa Kemampuan Rendah di Indonesia
}

\author{
Indra Siregar ${ }^{1}$ dan Veny Triyana Andika Sari ${ }^{*}$ \\ Alumni Pendidikan Matematika, SPs UPI Bandung \\ Jalan Setiabudhi No.229, Bandung, Jawa Barat, Indonesia \\ 1dracakep28@gmail.com; ${ }^{2 *}$ venytriyana050113@gmail.com
}

Artikel diterima: 17-06-2020, direvisi: 26-09-2020, diterbitkan: 30-09-2020

\begin{abstract}
Abstrak
Tujuan dari penelitian ini adalah memberikan deskripsi mengenai pembelajaran matematika yang menerapkan strategi motivasi Green's mampu mendorong siswa yang memiliki kemampuan rendah semangat saat pembelajaran berlangsung. Gambaran pada artikel ini berupa penjelasan yang lebih rinci dibandingkan artikel sebelumnya, karena adanya foto siswa yang memperlihatkan tanggapan positif pada saat pembelajaran matematika menggunakan strategi motivasi Green's berlangsung. Metode pembelajaran matematika dengan strategi motivasi Green's terdiri dari empat prinsip yaitu mengukapkan bukti dari permasalahan, tersampaikannya aspirasi tinggi, memberikan opini (komentar) dan memberikan nilai atau hadiah. Metode penelitian berupa kualitatif dasar. Hasilnya berupa pendeskripsian pembelajaran matematika dengan menerapkan Green's Motivational Strategies merupakan gaya baru pembelajaran matematika karena dapat memunculkan motivasi dan kepercayaan diri. Oleh karena itu, pembelajaran matematika dengan menerapkan strategi motivasi Green's perlu dipertimbangkan untuk menjadi salah satu pembelajaran matematika gaya baru khususnya pada pendidikan matematika Indonesia.

Kata Kunci: Bahan Ajar, Pengajaran Matematika, Strategi Motivasi Green's
\end{abstract}

\section{Green's Motivation Strategies, A New Style of Mathematics Learning in Low Ability Students in Indonesia}

\begin{abstract}
The purpose of this study is to provide a description of mathematics learning that applies Green's motivation strategy to be able to encourage students who have low enthusiasm when learning takes place. The description in this article is a more detailed explanation than the previous article because there are photos of students who show positive responses when learning mathematics using Green's motivation strategy takes place. The mathematics learning method with Green's motivational strategy consists of four principles, namely providing evidence of the problem, conveying high aspirations, providing opinions (comments), and providing value (gifts). The research method is a basic qualitative. The result is a description of mathematics learning by applying Green's Motivational Strategies, which is a new style of learning mathematics because it can generate motivation and self-confidence. Therefore, learning mathematics by applying Green's motivational strategy needs to be considered to be a new style of mathematics learning, especially in Indonesian mathematics education.

Keywords: Teaching Material, Mathematics Teaching, Green's Motivational Strategies
\end{abstract}




\section{Pendahuluan}

Kepercayaan diri siswa terbukti mampu ditingkatkan melalui perpaduan konsep bahan ajar yang selalu diperbaharui menggunakan strategi motivasi Green's (Siregar, Darhim, \& Asih, 2017). Dengan kata lain, konsep bahan ajar yang terus diperbaharui bisa menjadi motivasi tersendiri bagi siswa. Hal tersebut sejalan dengan pengertian kepercayaan diri yang diungkapkan Sudrajat (Nurojab \& Sari, 2019) yakni "motivasi dan kemampuan diri yang dihubungkan pada keadaan yakin dalam diri sendiri". Sehingga bahan ajar dengan konsep baru yang menerapkan pembelajaran motivasi Green's dapat menjadi salah satu alternatif dalam meningkatkan motivasi dan kemampuan diri siswa itu sendiri. Walaupun, konsep materi dari pengajaran yang diperbaharui dijelaskan secara sederhana, tetapi penerapan konsepnya bisa menjadi dasar terciptanya pembelajaran bermakna (Sugiarti \& Basuki, 2014; Matitaputy, 2016; Nanang \& Sukandar, 2020). Hal ini senada dengan teori Ausubel (Rahmah, 2013; Najib \& Elhefni, 2016) bahwa supaya terlaksananya belajar bermakna maka guru dituntut untuk berusaha terus mencari tahu wawasan seluas-luasnya dan siswa yang sudah memiliki konsep sebaiknya terus digali dan dibimbing untuk memadukannya dengan ilmu yang baru diterimakan secara harmonis. Jadi, penelitian ini, mendeskripsikan tentang bagaimana memunculkan motivasi siswa temuan Sari (2019) menyatakan bahwa "Pada faktanya, masih banyak siswa yang belum menguasai kemampuan pemahaman ini. Faktor utama belum menguasai kemampuan pemahaman karena tidak memahami konsep materi yang diajarkan".

Fakta tersebut menjadikan permasalahan yang terus menerus muncul ketika siswa dihadapkan dengan persoalan yang tidak biasanya (non-rutin) dikerjakan. Siswa yang demikian disebut sebagai siswa 
dengan kategori siswa yang memiliki kemampuan rendah. Sependapat dengan Hendryawan, Yusuf, Siregar, \& Dwiyanti (2017) yang menyatakan bahwa kemampuan rendah dimiliki siswa yang masih kesulitan mengerjakan soal-soal non-rutin. Walaupun demikian Kategori siswa tersebut mampu ditingkatkan motivasi belajarnya dengan menerapkan strategi motivasi Green's, karena kepercayaan diri siswa bukan satu-satunya yang dapat ditingkatkan oleh bahan utama strategi motivasi Green's, tetapi pengajaran matematika dengan gaya baru juga dapat dihasilkan.

Kebaruan gaya pembelajaran pada motivasi Green's berupa pemberian semangat untuk belajar matematika bukan dengan tugas. Biasanya siswa yang dikategorikan mempunyai kemampuan rendah akan diberikan tugas yang lebih banyak oleh guru supaya kemampuannya meningkat. Pemberian tugas yang lebih banyak didukung oleh pendapat Hasanah (2016) yang menjelaskan pemahaman dan latihan yang berulang-ulang kepada siswa sampai siswa benar-benar mengerti tentang pelajaran yang diberikan merupakan cara mengatasi siswa berkemampuan rendah, kemudian biasanya siswa didekati guru secara individu dan siswa ditanya kesulitan yang dialaminya saat ada konsep yang belum dipahami. Namun, hal tersebut berbeda dengan perlakuan yang diberikan kepada siswa dengan penerapan strategi motivasi Green's pada pembelajaran matematika.
Perlakuan siswa dengan penerapan strategi motivasi Green's berupa pemberian tes (soal) mulai dari level mudah hingga sulit, sehingga semangat siswa tertantang dalam pembelajaran matematika walaupun tanpa pidato motivasi (Siregar et al., 2017). Perlakuan tersebut juga didukung oleh Semiawan (Abdullah, 2017) yang menyatakan bahwa jika mengajar sesuai dengan perkembangan intelektual siswa maka kegiatan belajar akan menjadi lebih efektif. Selain itu, keefektifan dan keberhasilan dalam pembelajaran tidak terlepas dari adanya motivasi, sebabnya motivasi yang tinggi hanya dimiliki oleh siswa yang belajar dengan sungguh-sungguh (Tarlina \& Afriansyah, 2016; Fauziah, Safiah, \& Habibah, 2017; Yenni \& Sukmawati, 2020). Penelitian lain, menyatakan bahwa bahan ajar (materi) yang menarik perhatian siswa dan sesuai dengan kebutuhan siswa menjadikan siswa memiliki motivasi yang lebih (Ma'ruf, Syafi'i, \& Kusuma, 2019). Hal tersebut yang dirasakan siswa pada saat pembelajaran matematika menggunakan Green's Motivation Strategies (GMS), sehingga belajar matematika di kelas dinikmati siswa, tanpa pedulikan jam istirahat tiba. Selain itu, pendapat Fakhrurrazi (2018) memperjelas bahwa keberhasilan pengajaran sangat bertumpu pada keahlian guru dalam mengkondisikan kelas guna menciptakan situasi belajar yang kondusif bagi siswa. Selain mengkondisikan kelas agar pengajaran berhasil, ada yang paling penting yakni 
pengajaran itu sendiri (Mayasari \& Afriansyah, 2016; Faruqi, 2018; Nursyahidah, Saputro, Albab, \& Aisyah, 2020). Jadi, supaya pengajaran dan pembelajaran matematika bisa lebih efektif dan sukses perlunya keahlian dalam mengkondisikan kelas dan merencanakan pengajaran sebaik mungkin.

Pengajaran dan pembelajaran tersebut harus terus diperbaharui guna menarik perhatian siswa. Untuk itu, artikel ini juga bertujuan memberikan referensi baru dalam pembelajaran matematika dengan menerapkan Strategi motivasi Green's. Strategi motivasi Green's ini memiliki empat prinsip dasar, yaitu mengukapkan bukti dari permasalahan, tersampaikannya aspirasi tinggi, memberikan opini (komentar) dan memberikan nilai (hadiah) (Siregar et al., 2017). Setiap prinsip dasar yang disebutkan tersebut mempunyai bagian tersendiri untuk membangkitkan semangat baru bagi siswa. Untuk itu, gambaran pembelajaran matematika yang menerapkan strategi motivasi Green's dapat menjadi gaya baru pembelajaran dijelaskan secara rinci pada bagian hasil dan pembahasan.

\section{Metode}

Metode penelitian pada artikel ini yakni kualitatif dasar, dengan jenis penelitian penelitian deskriptif. Penelitian deskriptif ini sesuai dengan penjelasan Syaodih (Anwar \& Amin, 2013) yakni suatu metode penelitian yang ditujukan untuk menggambarkan fenomena-fenomena yang ada, yang berlangsung pada saat ini atau saat yang lampau. Langkah-langkah penelitian jenis deskriptif meliputi pengumpulan data, menyusun data, analisis data dan interpretasi data. Untuk pengumpulan data dan penyusunan data merupakan penelitian kuantitatif yang peneliti lakukan pada saat tahun 2016 akhir. Sedangkan artikel ini dibuat fokus pada analisis data dan interpretasi data secara kualitatif. Analisis data meliputi penjelasan materi (bahan) ajar dan gaya berdasarkan Green's Motivation Strategies (GMS) sedangkan interpretasi data berupa deskripsi kegiatan saat material pengajaran (bahan ajar) berdasarkan GMS dilaksanakan. Subjek penelitian diberikan pada siswa dengan kemampuan rendah di salah satu sekolah di Indonesia.

\section{Hasil dan Pembahasan}

\section{A. Penjelasan Materi Ajar Berdasarkan Green's Motivation Strategies (GMS)}

Prinsip dari GMS yang menjadi dasar dari bahan ajar yakni mampu mengungkapkan kepercayaan diri dan aspirasi yang tinggi. Contoh produk dapat dilihat pada Gambar 1. 


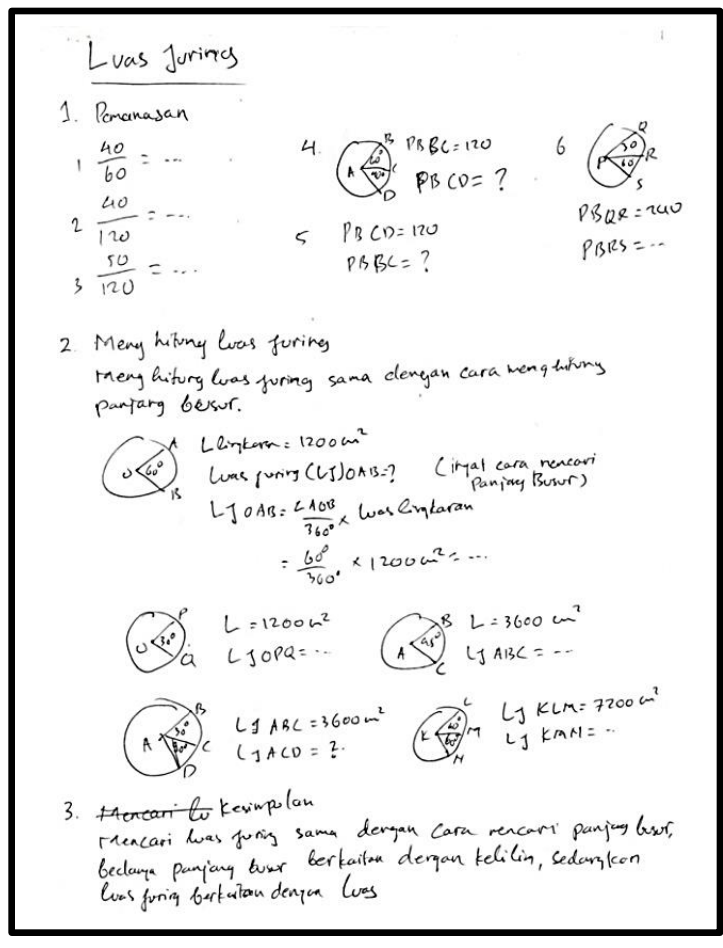

Gambar 1. Bahan Ajar Berbasis GMS (Siregar et al., 2017).

Konsep matematika yang terlihat pada Gambar 1., siswa diharapkan mampu menghitung besar sector pada lingkaran. Sesuai prinsip kepercayaan confeying pada GMS, guru harus merencanakan masalah (soal) matematika mudah yang agar konsep matematika dasar dipahami. Jadi, konsep matematika dasar dalam menghitung besar daerah suatu lingkaran dan membuat beberapa masalah (soal) matematika harus dieksplor sedemikian rupa oleh Peneliti.

Siswa melaksanakan kegiatan counting dengan lebih mudah karena kesetaraan persamaan fraksi pada masalah (soal) yang diberikan. Jadi, masalah (soal) matematika dari persamaan fraksi adalah masalah mudah bagi siswa kelas 8 di sekolah menengah pertama karena konsep dasarnya sudah siswa dapatkan pada jenjang sekolah dasar. Jumlah yang dipilih pada masalah kesetaraan harus sama dengan jumlah soal latihan satu konsep matematika. Pada Gambar 1., bilangan yang digunakan dalam menghitung luas juring pada satu subjek (lingkaran) adalah 1200 dan 3600. tetapi, bilangan yang digunakan dalam menghitung luas juring yang digunakan pada satu masalah matematika mudah adalah 60 dan 120. Masalah matematika mudah disebut masalah pemanasan. Begitu juga pola berpikir similar (serupa) dimiliki saat menghitung panjang busur. Jadi, menghitung panjang busur terlebih dahulu dapat membantu siswa untuk menyiapkan pola berpikir dalam menghitung besar suatu daerah.

Prinsip aspirasi yang tinggi dalam menyampaikan GMS membuat materi pengajaran lebih menantang. Aspirasi yang disampaikan guru kepada siswa berupa penilaian setiap adanya kesulitan yang terjadi pada masalah mudah (soal pemanasan) yang diberikan. Kemudian masalah (soal) selanjutnya harus lebih sulit dari masalah sebelumnya guna memberikan tantangan yang lebih bagi siswa. Konsep matematik menantang diawali dari masalah (soal) seperti pada contoh soal (Gambar 1).

\section{B. Gaya Bahan Pengajaran Lainnya Berdasarkan Green's Motivation Strategies (GMS)}


Peneliti menyusun contoh lain dari bahan ajar dengan menerapkan GMS dengan konsep matematika dan pola yang berbeda. Bahan ajar disusun berpedoman pada pembelajaran berbasis masalah.

Pembelajaran berbasis masalah yang berupa menyelesaikan masalah (soal) bersama termasuk pada aktivitas inti pembelajaran. Pembelajaran berbasis masalah menjadi lebih cocok untuk siswa dengan kemampuan rendah jika GMS diterapkan dengan baik. Contoh masalah (soal) dapat dilihat pada Gambar 2.

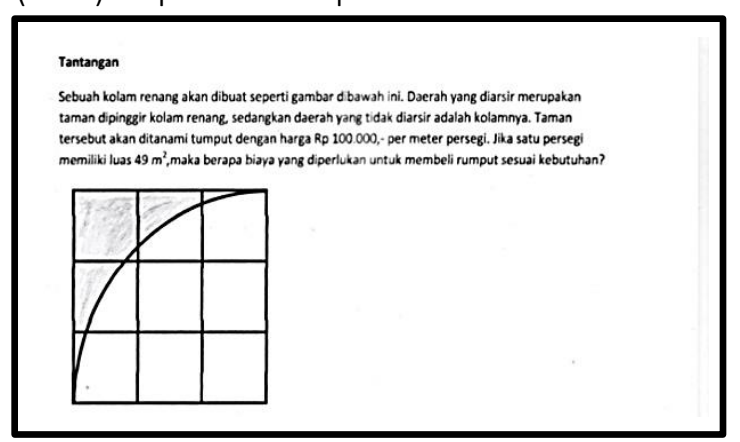

Gambar 2. Contoh Soal untuk Pembelajaran Berbasis Masalah.

Berdasarkan prinsip GMS, keyakinan dan aspirasi yang tinggi disampaikan dengan meberikan masalah (soal) pemanasan di Gambar 3. supaya siswa tertantang (support) untuk memecahkan masalah pada Gambar 2. Dari kedua contoh soal pada gambar memiliki Konsep dasar masalah yang kombinasi yakni antara konsep lingkaran yang berfokus pada menghitung besar lingkaran sedangkan konsep kuadrat berfokus pada luas persegi. Jadi, konsep matematika dasar pada masalah (soal) pemanasan adalah menentukan ukuran persegi dan lingkaran. Ada beberapa tipe permasalahan pada soal pemanasan pada Gambar 2., diantaranya lingkaran besar, persegi besar, pola yang berbeda dari yang kedua dikombinasikan dengan persegi besar, dan kolaborasi besar lingkaran dan persegi. Semua tipe permasalahan yang diberikan siswa pahami konsep matematika dasar sehingga permasalahan (persoalah) berikutnya menjadi permasalahan yang mudah bagi siswa.

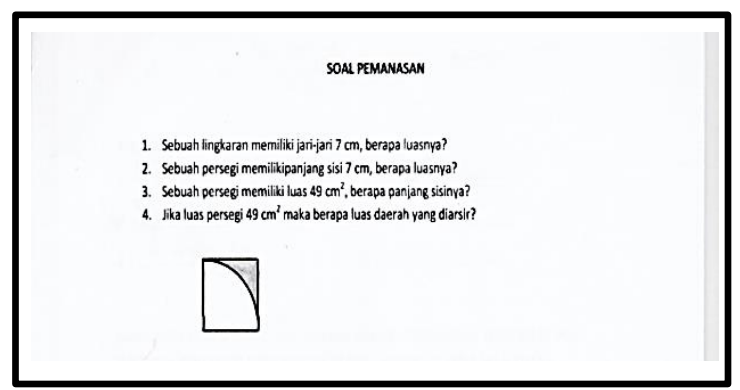

Gambar 3. Soal Pemanasan untuk Masalah Matematika pada Gambar 2.

\section{Deskripsi Kegiatan saat Meterial Pengajaran dilaksanakan}

Kegiatan belajar dan mengajar diawali dengan pemberian masalah (soal) pemanasan. Selama melakukan kegiatan tersebut, siswa tidak mengetahui tentang aktifitas utama (inti).

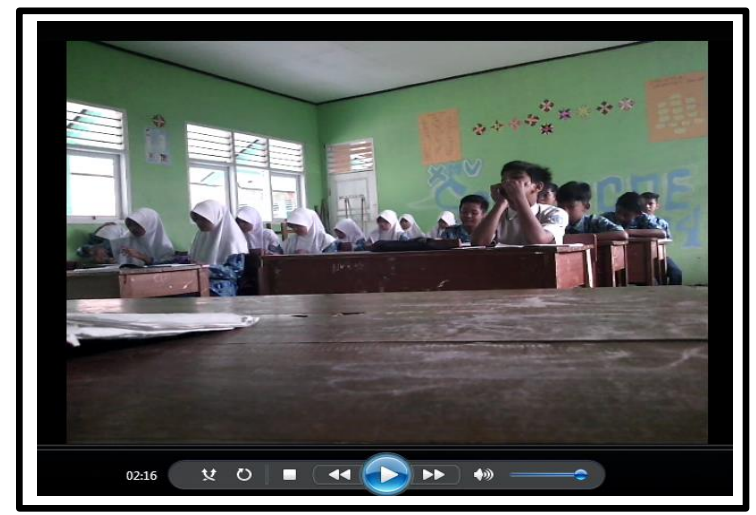

Gambar 4. Ekspresi Siswa ketika Kelas Baru Saja dimulai. 
Gambar 4. menunjukkan siswa masih dalam kondisi santai dalam memahami tes (soal) pemanasan yang dituliskan pada papan tulis di depan kelas. Selang beberapa detik kemudian dapat diperhatikan pada Gambar 5.

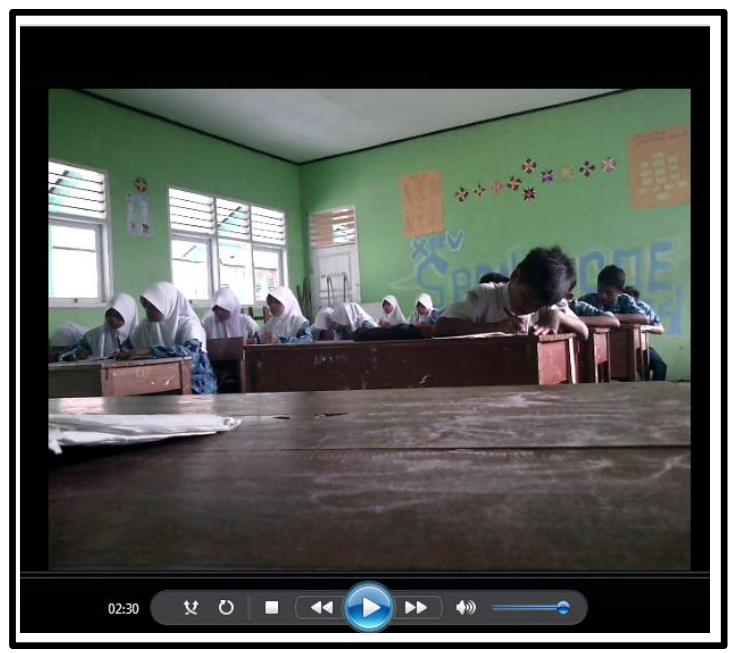

Gambar 5. Perubahan Ekspresi Siswa setelah Memahami Tes (Soal) Pemanasan.

Pada Gambar 5. tampak perubahan ekspresi siswa setelah 14 detik, semua siswa pada kondisi serius. Masalah mudah mengubahnya dengan cepat. Pada video lengkap, hal guru tidak bayak melakukan kegiatan kecuali hanya memberikan masalah (soal) pemanasan.

Selanjutnya pada Gambar 6. Sudah terlihat siswa yang beranjak dari tempat duduknya untuk memperlihatkan hasil pengerjaannya dalam memecahkan soal pemanasan yang diberikan kepada guru. Siswa tersebut terlihat bahagia ketika berhasil menyelesaikan soal yang diberikan, ini memperlihatkan respons positif tentang pembelajaran matematika. Karena biasanya pembelajaran matematika selalu dianggap sulit dan membosankan, tetapi berbeda jika menerapkan strategi Green's motivasi ini apalagi untuk mengatasi siswa yang memiliki kemampuan rendah.

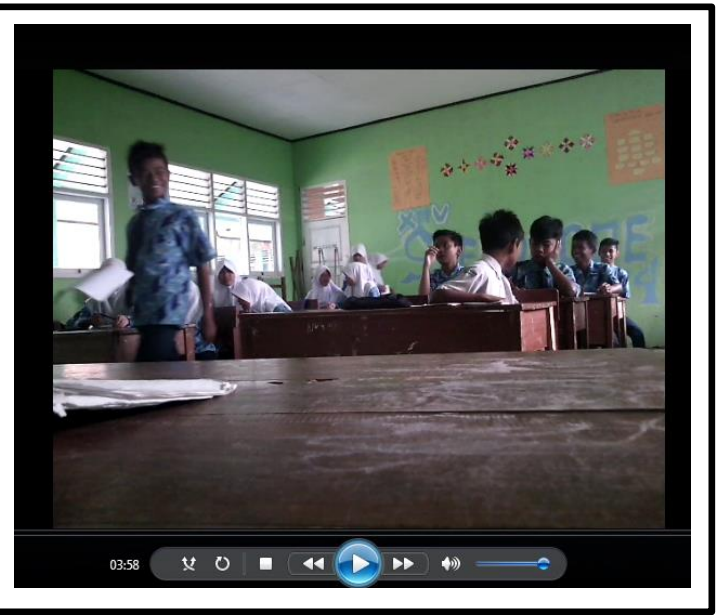

Gambar 6. Ekspresi Beberapa Siswa ketika Sukses Menyelesaikan Soal Pemanasan.

Kemudian saat salah satu siswa beranjak dari tempat duduknya untuk memperlihatkan hasil yang diperoleh, siswa yang lain terlihat masih terus berusaha dan tidak patah semangat untuk memecahkan soal pemanasan yang diberikan. Hal tersebut terlihat pada Gambar 7. tepatnya diwaktu 34 detik setelah salah satu siswa yang berhasil memecahkan soal pemanasan pertama masih berada di depan kelas untuk memperlihatkan hasil yang diperoleh. Hal tersebut merupakan respons positif lainnya dalam pembelajaran matematika yakni tidak mudah putus asa saat salah satu siswa berhasil. 


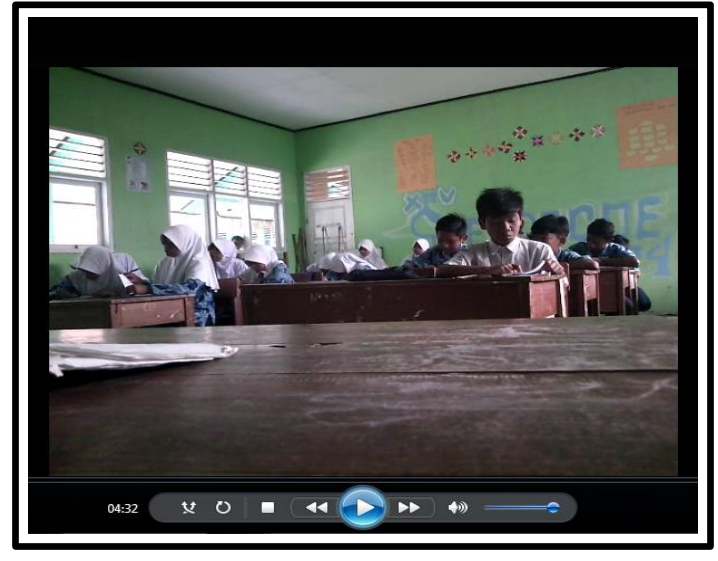

Gambar 7. Ekspresi Siswa Masih Tetap Semangat untuk Memecahkan Soal Pemanasan.

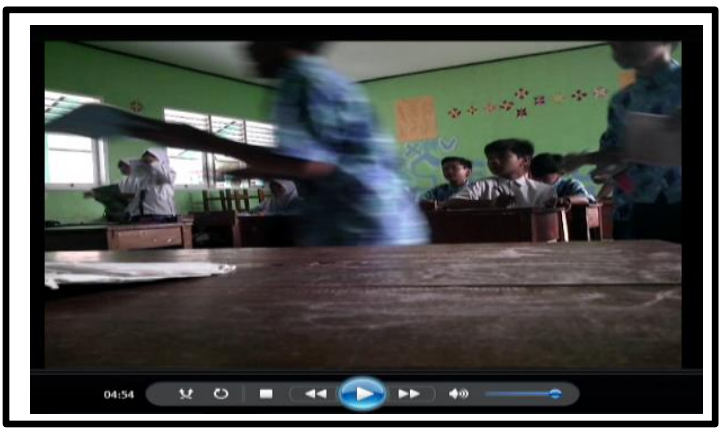

Gambar 8. Ekspresi Siswa Lainnya Saat Bisa Memecahkan Soal Pemanasan.

Pada Gambar 8, kita dapat melihat bagaimana ekspresi bahagia dari beberapa siswa. Tepatnya pada 22 detik, terlihat ada siswa yang berlari maju kedepan kelas dengan penuh kebahagian saat berhasil memecahkan soal pemanasan tersebut.

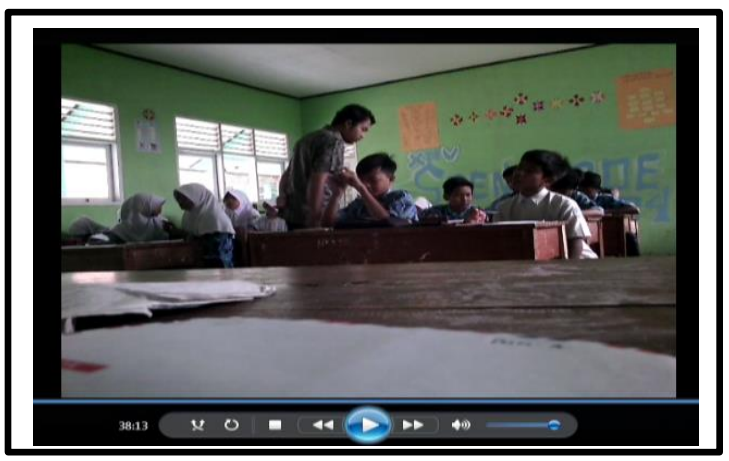

Gambar 9. Ekspresi Siswa ketika Mulai ke Kegiatan Belajar Utama (Kegiatan Inti).
Gambar 9. adalah kondisi ketika mulai ke aktivitas belajar utama (aktivitas inti). Jika Anda melihat gambar pada Gambar 4, 5, 6, 7 dan 8, siswa laki-laki yang duduk di baris pertama hanya satu orang. Tetapi, pada Gambar 9. ini, siswa laki-laki yang duduk di baris pertama adalah dua orang. Ini bukti bahwa siswa itu keluar dari aktivitas belajar, dan seharusnya guru memberikan respons dengan mendekati siswa tersebut serta memberikan arahan agar siswa dapat kembali mengikuti aktivitas inti. Namun pada video selengkapnya, siswa yang baru duduk kembali ke tempat duduknya tidak diberikan instruksi apa pun dari guru. Sedangkan siswa berusaha untuk tetap mengikuti aktivitas inti secara mandiri tanpa arahan guru. Hal tersebut menunjukkan siswa tersebut secara tidak langsung sudah mendapatkan motivasi melalui semangat siswa lainnya saat berhasil memecahkan masalah (soal) pemanasan yang diberikan.

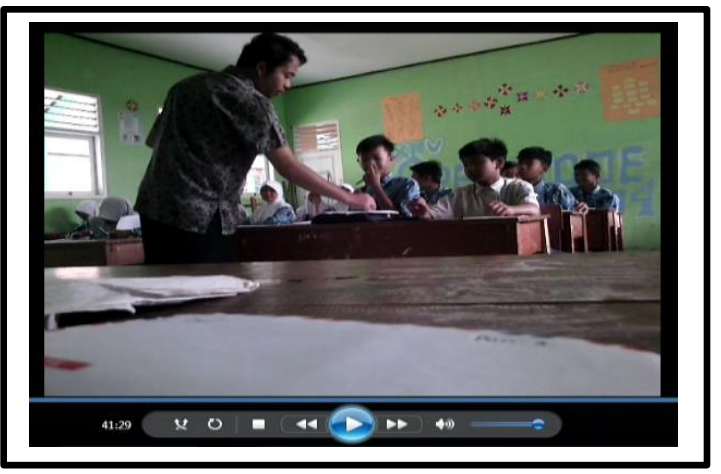

Gambar 10. Ekspresi Para Siswa yang Semangat Mengerjakan Soal Pemanasan Berikutnya.

Kemudian di Gambar 10. terlihat para siswa masih fokus untuk menyelesaikan masalah lain. Sedangkan kegiatan guru 
hanya berkeliling di kelas, memberikan komentar kepada beberapa siswa, dan memberikan tanda tangan (hadiah) kepada siswa yang berhasil. Hal ini menjadi bagian penting dalam prinsip GMS untuk menunculkan rasa bangga pada diri (percaya diri) siswa sesering mungkin.

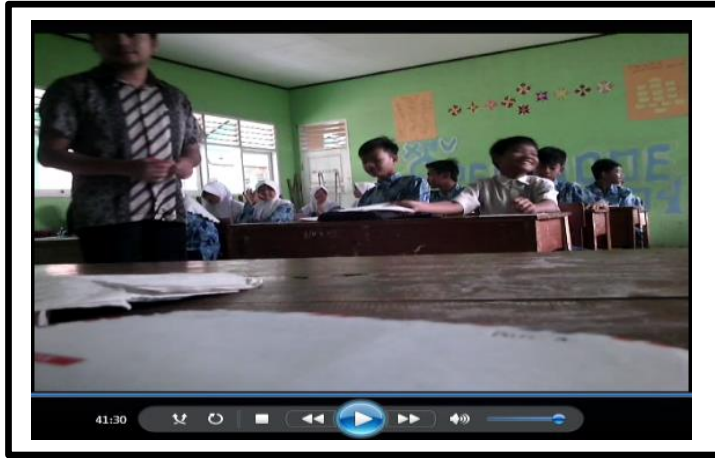

Gambar 11. Ekspresi Siswa Setelah Mendapatkan Bukti Aspirasi oleh Guru.

Prinsip GMS tentang kegiatan pemanasan hanya fokus pada mengukapkan bukti dari permasalahan, tersampaikannya aspirasi tinggi, memberikan opini (komentar) dan memberikan nilai (hadiah). Keempat prinsip GMS tersebut dapat terlaksana jika guru menyiapkan banyak masalah (soal) mudah suapaya siswa punya banyak kesempatan untuk bersaing menyelesaikan masalah sebanyak mungkin. Hal tersebut didukung oleh pendapat Rudhumbu (2014) yang menyatakan bahwa kepercayaan dapat dimunculkan oleh guru dengan mengatur situasi kelas agar siswa yang memiliki kemampuan tingkat rendah pun bersemangat, bahkan ikut serta dalam mendapatkan kesuksesan menyelesaikan soal secara berulang-ulang. Semua prinsip
GMS diterapkan pada saat kegiatan utama (inti) berlangsung, menyebabkan motivasi intrinsik akedemik didapatkan siswa karena siswa mengerjakan masalah pemanasan dengan penuh kesenangan (Middleton \& Spanias (Siregar, Darhim, \& Asih, 2017)).

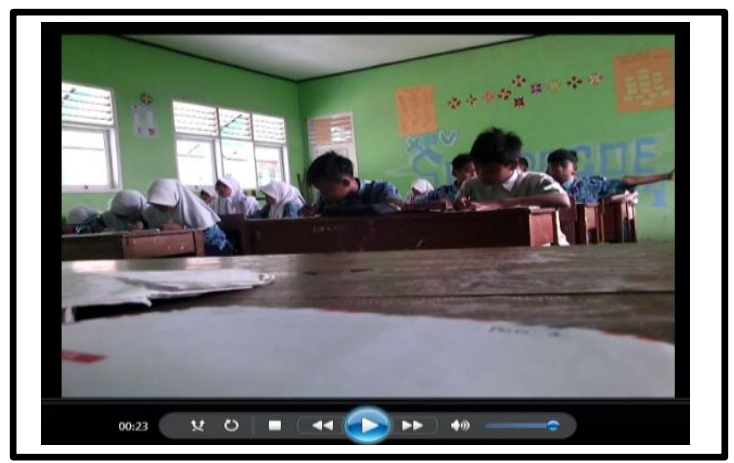

Gambar 12. Ekspresi Siswa dimenit Terakhir Ketika akan Berakhir Pembelajaran.

Selanjutnya, pada Gambar 12. Merupakan detik-detik pembelajaran akan berakhir. Siswa terlihat masih memfokuskan diri mengikuti pembelajaran. Hal ini menandakan bahwa semangat siswa semakin meningkat selama pembelajaran berlangsung dan menjadi bukti nyata keberhasilan pembelajaran matematika dengan gaya baru yakni menerapkan strategi Green's motivasi.

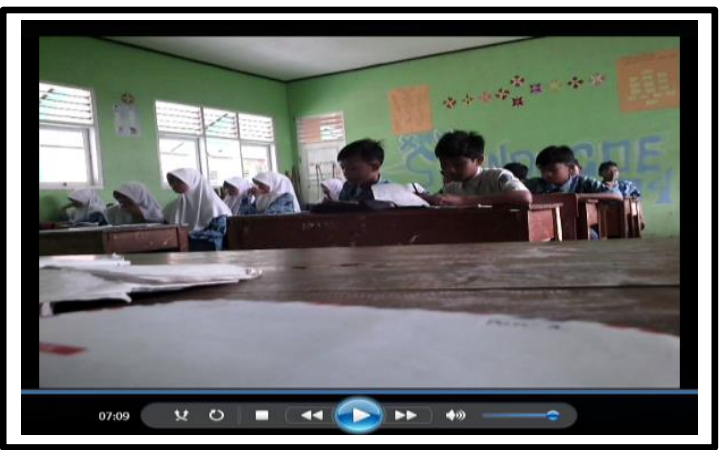

Gambar 13. Ekspresi Siswa yang Masih Fokus disaat Akhir Pembelajaran 
Begitu juga pada menit terakhir aktivitas kelas ditunjukkan Gambar 13., siswa masih tetap fokus belajar. Kefokusan itu memperlihatkan semangat siswa yang stabil dari sejak awal. Kunci utama agar bisa memotivasi siswa dalam pembelajaran matematika bukan hanya menggunakan pidato motivasi tetapi memotivasi siswa dengan soal-soal pemanasan.

Kesimpulan dari artikel ini berupa pendeskripsian pembelajaran matematika dengan menerapkan Green's Motivational Strategies merupakan gaya baru pembelajaran matematika karena dapat memunculkan motivasi dan kepercayaan diri. Adanya motivasi daan kepercayaan diri siswa terlihat pada saat siswa fokus dan berusaha keras menyelesaikan masalah matematika yang memiliki kategori mudah (soal pemanasan). Kefokusan dan usaha keras siswa itu dapat ditularkan pada siswa lain yang kurang semangat seperti yang diperlihatkan pada Gambar 9.

\section{Penutup}

Penelitian ini merupakan penelitian sederhana. Oleh karena itu penelitian lebih profesional dengan biaya lebih banyak masih dibutuhkan peneliti serta peneliti berharap peneliti lain bisa mengadakan penelitian serupa dengan subjek yang berbeda guna menambah referensi tentang implementasi Green's Motivation Strategies (GMS) di Indonesia. Peneliti percaya bahwa Green's
Motivational Strategies mampu menjadi solusi dalam mengatasi kemampuan siswa yang masih dibawah rata-rata dan meningkatkan pendidikan matematika Indonesia.

\section{DAFTAR PUSTAKa}

Abdullah. (2017). Pendekatan dan Model Pembelajaran yang Mengaktifkan Siswa. Edureligia, 1(1), 45-62.

Anwar, S., \& Amin, S. M. (2013). Penggunaan Langkah Pemecahan Masalah Polya dalam Menyelesaikan Soal Cerita pada Materi Perbandingan di Kelas VI Mi Al-Ibrohimy Galis Bangkalan. Jurnal Pendidikan Matematika E-Pensa, 1(1), 1-6.

Dewi, S. S. S., \& Afriansyah, E. A. (2018). Kemampuan Komunikasi Matematis Siswa Melalui Pembelajaran CTL. JIPMat, 3(2), 145-155.

Fakhrurrazi. (2018). Hakikat Pembelajaran yang Efektif. Jurnal Al-Tafkir, XI(1), 85-99.

Faruqi, D. (2018). Upaya Meningkatkan Kemampuan Belajar Siswa melalui Pengelolaan Kelas. Evaluasi, 2(1), 294-310.

Fauziah, Safiah, I., \& Habibah, S. (2017). Upaya Meningkatkan Motivasi Belajar Siswa melalui Lesson Study di Kelas V SD Negeri Lampagen Aceh Besar. Jurnal IImiah Pendidikan Guru Sekolah Dasar, 2(1), 30-38.

Hasanah, N. (2016). Upaya Guru dalam Mengatasi Siswa Berkesulitan Belajar 
Matematika di Kelas IV SDIT Ukhuwah Banjarmasin. Jurnal PTK \& Pendidikan, 2(2), 27-34.

Hernandes, V., Isnaini, M., \& Testiana, G. (2016). Pengembangan Bahan Ajar Matematika Menggunakan Komputer pada Materi Kesebangunan di Kelas IX MTs Negeri 1 Palembang. Mosharafa: Jurnal Pendidikan Matematika, 5(3), 281-292.

Ma'ruf, A. H., Syafi'i, M., \& Kusuma, A. P. (2019). Pengaruh Model Pembelajaran Mind Mapping Berbasis HOTS terhadap Motivasi dan Hasil Belajar Siswa. Mosharafa: Jurnal Pendidikan Matematika, 8(3), 503514.

Matitaputy, C. (2016). Miskonsepsi Siswa dalam Memahami Konsep Nilai Tempat Bilangan Dua Angka. Mosharafa: Jurnal Pendidikan Matematika, 5(2), 113-119.

Mayasari, Y. (2016). Kemampuan Koneksi Matematis Siswa Melalui Model Pembelajaran Berbasis Masalah (Studi Penelitian di SMP Negeri 5 Garut). Jurnal Riset Pendidikan, 2(01), 27-44.

Middleton, J. A., \& Spanias, P. A. (1999). Motivation for Achievement in Mathematics: Findings, Generalizations, and Criticisms of the Research. Journal for Research in Mathematics Education, 30(1), 6588.

Najib, D. A., \& Elhefni. (2016). Pengaruh Penerapan Pembelajaran Bermakna
(Meaningfull Learning) Pada Pembelajaran Tematik IPS Terpadu Terhadap Hasil Belajar Siswa Kelas III di MI Ahliyah IV Palembang. JIP: Jurnal IImiah PGMI, 2(1), 19-28.

Nanang, N., \& Sukandar, A. (2020). Meningkatkan Kemampuan Siswa SDIT Miftahul Ulum Pada Operasi Bilangan Bulat Melalui CAIContextual. Mosharafa: Jurnal Pendidikan Matematika, 9(1), 71-82.

Nasution, M. D., Nasution, E., \& Haryati, F. (2017). Pengembangan Bahan Ajar Metode Numerik dengan Pendekatan Metakognitif Berbantuan MATLAB. Mosharafa: Jurnal Pendidikan Matematika, 6(1), 69-80.

Nurojab, E. S., \& Sari, V. T. A. (2019). Hubungan Self Confidence terhadap Kemampuan Pemecahan Masalah Matematik Siswa. JPMI: Jurnal Pembelajaran Matematika Inovatif, 2(5), 329-336.

Nursyahidah, F., Saputro, B. A., Albab, I. U., \& Aisyah, F. (2020). Pengembangan Learning Trajectory Based Instruction Materi Kerucut Menggunakan Konteks Megono Gunungan. Mosharafa: Jurnal Pendidikan Matematika, 9(1), 47-58.

Rahmah, N. (2013). Belajar Bermakna Ausubel. Al- Khwarizmi, 1, 43-48.

Rudhumbu, N. (2014). Motivational Strategies in the Teaching of Primary School Mathematics in Zimbabwe. International Journal of Education Learning and Development UK, 2(2), 
76-103.

Sari, V. T. A. (2019). Students' Understanding Ability in Solving Algebraic Problems. JEE(Journal of Education Experts, 2(2), 89-96.

Sari, V. T. A., \& Nurfauziah, P. (2019). Development of Trigonometry Teaching Materials with Knisley Mathematical Models. In Proceedings ICSTI 2018, October 19-20, Yogyakarta, Indonesia (pp. 1-8). EAI.

Setyaningrum, D. U., \& Mampouw, H. L. (2020). Proses Metakognisi Siswa SMP dalam Pemecahan Masalah Perbandingan Senilai dan Berbalik Nilai. Mosharafa: Jurnal Pendidikan Matematika, 9(2), 275-286.

Siregar, I., Darhim, \& Asih, E. C. M. (2017). Increasing Self-Confidence of Indonesian Low Ability Student with Green's Motivational Strategies. Journal of Physics: Conference Series, 812(012104), 1-6.

Sugiarti, S., \& Basuki, B. (2018). Pengaruh Model Pembelajaran Berbasis Masalah terhadap Kemampuan Koneksi Matematis Siswa dalam Pembelajaran

Matematika. Mosharafa, 3(3), 151158.

Suryani, M., Jufri, L. H., \& Putri, T. A. (2020). Analisis Kemampuan Pemecahan Masalah Siswa Berdasarkan Kemampuan Awal Matematika. Mosharafa: Jurnal Pendidikan Matematika, 9(1), 119130.
Tarlina, W. H., \& Afriansyah, E. A. (2016). Kemampuan Berpikir Kreatif Siswa Melalui Creative Problem Solving. Eduma: Mathematics Education Learning and Teaching, 5(2), 42-51.

Yenni, Y., \& Sukmawati, R. (2020). Analisis Kemampuan Representasi Matematis Mahasiswa Berdasarkan Motivasi Belajar. Mosharafa: Jurnal Pendidikan Matematika, 9(2), 251-262.

\section{Riwayat Hidup PENUlis Indra Siregar, M.Pd.}

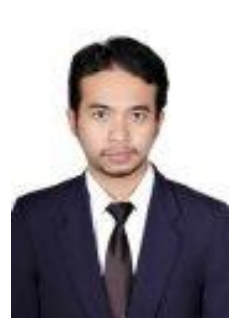

Lahir di Cianjur, 28 Juni 1987. Staf pengajar di STKIP Sebelas April Sumedang. Studi S1 Pendidikan Matematika, Universitas Surya Kencana (UNSUR), Cianjur, lulus tahun (2009); S2 Pendidikan Matematika, Universitas Pendidikan Indonesia (UPI), Bandung, lulus tahun (2012); dan S3 Pendidikan Matematika Universitas Pendidikan Indonesia, Bandung, dari tahun (2013-sekarang).

\section{Veny Triyana Andika Sari, M.Pd.}

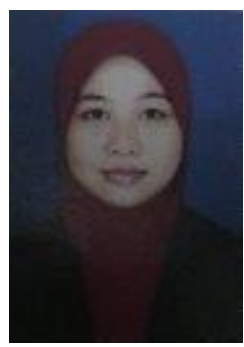

Lahir Bekasi, 9 Juni 1987. Pernah menjadi staf pengajar di IKIP Siliwangi. Studi S1 Pendidikan Matematika, Universitas Muhammadiyah Prof. DR. Hamka (UHAMKA), Jakarta, lulus tahun (2009); dan S2 Pendidikan Matematika Universitas Pendidikan Indonesia (UPI) Bandung, lulus tahun (2012). 